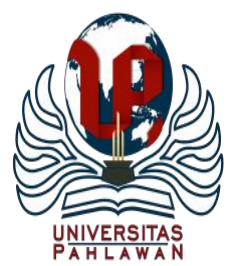

Jurnal Abdidas Volume 2 Nomor 3 Tahun 2021 Halaman 617-626

JURNAL ABDIDAS

http://abdidas.org/index.php/abdidas

\title{
Revitalisasi Pembelajaran Kitab Kuning di Era Revolusi Industri 4.0 bagi Mahasiswa di Pondok Pesantren Tahfidz Al-Qur'an "Oemah Al-Qur'an" Merjosari Lowokwaru Malang
}

\author{
Nur Chanifah \\ Ilmu Hukum, Fakultas Hukum, Universitas Brawijaya Malang, Indonesia \\ E-mail: nur.chanifah@ub.ac.id
}

\begin{abstract}
Abstrak
Tantangan pesantren di era revolusi industri 4.0 adalah menghadapi kecanggihan teknologi informasi dan komunikasi yang menimbulkan berbagai macam perubahan aspek kehidupan. Pesantren tidak bisa lagi bersikukuh mengunakan metode konvensional, seperti ceramah (sorogan dan bandongan). Akan tetapi, media pembelajaran yang dilaksanakan oleh pesantren tersebut masih minim, mengingat fasilitas dan dana yang terbatas. Oleh karena itu, perlu adanya solusi dan pendampingan dalam rangka revitalisasi media pembelajaran kitab kuning di pesantren tersebut. Metode yang digunakan adalah dengan sosialisasi tentang pentingnya revitalisasi media pembelajaran kitab kuning ke pesantren, kemudian dilanjutkan dengan pendampingan penerapan media pembelajaran kitab kuning berbasis teknologi. Hasilnya menunjukkan bahwa untuk revitalisasi media pembelajaran kitab kuning di pesantren, maka perlu ada beberapa hal yang perlu diperhatikan, yaitu: 1) mengubah mindset kyai atau ustadz tentang perlunya media pembelajaran berbasis teknologi, 2) penggunaaan media berbasis teknologi harus diimbangi dengan pengetahuan agama yang mendalam agar tidak disalahgunakan, 3) Pengguna media berbasis teknologi harus tetap mengontrol kegiatan pembelajaran secara langsung sebagai upaya untuk mengantisipasi pengaruh negatif dari teknologi.
\end{abstract}

Kata kunci: revitalisasi, kitab kuning, revolusi industri 4.0

\section{Abstract}

The challenge of pesantren in the era of the industrial revolution 4.0 is to face the sophistication of information and communication technology that causes various changes in aspects of life. Pesantren can no longer insist on using conventional methods such as lectures (sorogan and bandongan). However, the learning media implemented by the pesantren are still minimal, given the limited facilities and funds. Therefore, there is a need for solutions and assistance in the context of revitalizing the "kitab kuning" learning media in the pesantren. The method used is to socialize about the importance of revitalizing the "kitab kuning" learning media to Islamic boarding schools then followed by mentoring the application of technology-based "kitab kuning" learning media. The results show that to revitalize the yellow book learning media in Islamic boarding schools, there are several things that need to be considered, namely: 1. Changing the mindset of kyai or ustdaz about the need for technology-based learning media, 2. The use of technology-based media must be balanced with deep religious knowledge so as not to be misused, 3. Users of technology-based media must continue to control learning activities directly as an effort to anticipate the negative effects of technology.

Keywords: revitalitation, kitab kuning, industrial revolution 4.0

Copyright (c) 2021 Nur Chanifah

$\triangle$ Corresponding author

Address : Fakultas Hukum Universitas Brawijaya

Email: nur.chanifah@ub.ac.id

DOI : https://doi.org/10.31004/abdidas.v2i3.329

ISSN 2721-9224 (Media Cetak)

ISSN 2721- 9216 (Media Online) 
618 Revitalisasi Pembelajaran Kitab Kuning di Era Revolusi Industri 4.0 bagi Mahasiswa di Pondok Pesantren Tahfidz al-Quran "Oemah al-Quran” Merjosari Lowokwaru Malang- Nur Chanifah DOI: https://doi.org/10.31004/abdidas.v2i3.329

\section{PENDAHULUAN}

Pesantren merupakan salah satu lembaga pendidikan yang sudah berkembang sejak zaman penjajahan. Pengaruhnya sangat siginifikan dalam membangun dan mencerdaskan bangsa Indonesia. Banyak tokoh-tokoh penting yang berpengaruh bagi bangsa ini yang merupakan lulusan pesantren. Untuk itu, peran pesantren tidak boleh dianggap remeh. (Khoirurrijal, 2019).

Di Indonesia, secara legal formal eksistensi pesantren di Indonesia diakui berdasarkan Undangundang Nomor 20 tahun 2003 tentang Sistem Pendidikan Nasional. Pasal 30 ayat 4 yang berbunyi, "pendidikan keagamaan berbentuk pendidikan diniyah, pesantren, pasraman, pabhaja samanera, dan bentuk lain yang sejenis." (Nata, 2012) Dalam pasal tersebut dijelaskan bahwa pesantren berfungsi sebagai satuan pendidikan yang dipersiapkan agar mampu memahami dan mengamalkan nilai-nilai ajaran agamanya dan/atau menjadi ahli ilmu agama. Undang-undang tersebut dikuatkan kembali dalam Peraturan Pemerintah Nomor 55 tahun 2007 tentang Pendidikan Agama dan Pendidikan Keagamaan. Peraturan tersebut di pertegas dengan Peraturan Menteri Agama (PMA) Nomor 13 Tahun 2014 tentang Pendidikan Keagamaan Islam yang menjelaskan secara khusus di antaranya mengenai nomenklatur pondok pesantren. Bahkan, tidak hanya itu, pondok pesantren mendapatkan penegasan lebih lanjut melalui Peraturan Menteri Agama Nomor 18 Tahun 2014 tentang Satuan Pendidikan Muadalah pada Pondok Pesantren.

Sejak awal, pesantren dikenal sebagai lembaga keislaman yang memiliki nilai-nilai strategis dalam pengembangan masyarakat Indonesia yang telah tumbuh dan berkembang di berbagai daerah. (Wiwin Fitriyah,
2018) Pesantren telah menjangkau berbagai lapisan masyarakat, khususnya masyarakat muslim. Pondok pesantren memiliki peran penting dalam meningkatkan kualitas sumber daya manusia di Indonesia yang hanya memberikan pengetahuan dan keterampilan teknis, tetapi juga menanamkan nilai-nilai moral dan agama (Sadali, 2020).

Pesantren memiliki tradisi khas yang tidak dimiliki oleh lembaga pendidikan selain pesantren. Tradisi tersebut diwariskan dari generasi ke generasi untuk kelangsungan hidup pesantren. Pesantren merupakan salah satu lembaga pendidikan yang merepresentasikan pendidikan yang unik yang mensintesakan dimensi sosial, budaya dan agama (Ulum, 2018). Akar dan sintesis ini kemudian mempengaruhi fungsi pesantren, baik secara internal maupun eksternal. Dalam hal ini, pesantren menjadi wacana yang selalu hidup, dinamis, aktual dan segar untuk diperbincangkan, termasuk mengenai bagaimana fungsi sosial pesantren diperlukan dalam menghadapi modernitas di era digital yang ditandai oleh revolusi industry 4.0 (Gazali, 2018).

Salah satu karakter revolusi industry 4.0 adalah transformasi digital manufaktur dan pemanfaatan teknologi platform ketiga. Teknologi informasi menjadi basis dalam kehidupan manusia. Semuanya tanpa batas dengan penggunaan daya dan data komputasi tak terbatas, karena dipengaruhi oleh perkembangan internet dan teknologi digital masif sebagai tulang punggung gerakan manusia dan mesin serta konektivitasnya. Revolusi ini akhirnya mengubah perspektif seseorang dalam menjalani kehidupan modern dan canggih. Lebih lanjut, masuknya era RI 4.0 ditandai dengan kemunculan superkomputer, robotika, kendaraan tanpa pengemudi, editing genetik dan perkembangan neuroteknologi yang memungkinkan manusia untuk lebih mengoptimalkan 
619 Revitalisasi Pembelajaran Kitab Kuning di Era Revolusi Industri 4.0 bagi Mahasiswa di Pondok Pesantren Tahfidz al-Quran "Oemah al-Quran” Merjosari Lowokwaru Malang- Nur Chanifah DOI: https://doi.org/10.31004/abdidas.v2i3.329

fungsi otak, kecerdasan buatan (Artificial intelligence), big data, nano teknologi, komputasi quantum, seluruhnya ditujukan untuk kesejahteraan manusia (Gazali, 2018).

Dalam menghadapi era revolusi industri 4.0 tersebut, pesantren sebagai institusi pendidikan, keagamaan, dan sosial diharapkan melakukan kebijakan strategis dengan melakukan pembaharuan-pembaharuan adaptif terhadap kebutuhan masyarakat millinial terutama aspek pendidikan dan pemberdayaan masyarakat yang lebih accessible dan kontekstual tanpa harus mengorbankan watak aslinya sebagai penjaga tradisi dan budaya pendidikan Islam yang khas Indonesia. (Gazali, 2018)

Lebih jauh dari itu, di lingkungan pesantren dikenal istilah pembelajaran kitab kuning atau disebut juga dengan istilah kitab gundul atau kitab kuno (Mahfudh, 1994). Dalam tradisi intelektual Islam untuk penyebutan istilah kitab karya ilmiah para ulama itu dibedakan berdasarkan kurun waktu atau format penulisannya. Kategori pertama disebut kitab-kitab klasik (al-kutub al-qadimah), sedangkan kategori kedua disebut kitab-kitab modern (al-kutub al-'ashriyyah). Apa yang disebut dengan kitab kuning adalah pada dasarnya mengacu kepada kategori pertama yakni kitab klasik (alkutub al-qadimah) (Adawiyyah, 2017).

Kadangkala pengajaran materi kitab tersebut berulang-ulang meskipun berjenjang. Hanya berupa pendalaman dan perluasan wawasan santri. Memang ini menjadi salah satu bentuk penyelenggaraan pengajaran pondok pesantren yang diselenggarakan berdasarkan sistem (kurikulum) kitabi. Berdasarkan pada jenjang ringan beratnya muatan kitab. Tidak berdasarkan tematema (maudhlu'i) yang memungkinkan tidak terjadinya pengulangan namun secara komprehensif diajarkan pemateri pada para santri. Meski diajarkan dengan sistem kitabi tetap terjaga sistematika kitab, berdasarkan pada fan atau cabangnya (Adawiyyah, 2017).

Selain itu, metode popular yang sering digunakan dalam pembelajaran kitab kuning tersebut adalah metode sorogan dan bandongan. Metode sorogan merupakan metode yang lebih menitikberatkan pada pengembangan kemampuan perseorangan (santri) di bawah bimbingan kyai. Sedangkan metode bandongan yang sering juga disebut dengan istilah wetonan, merupakan metode yang diterapkan oleh seorang kyai terhadap sekelompok santri untuk mendengarkan dan menyimak apa yang dibacakan dari sebuah kitab (Arief, 2002).

Dalam implemetasinya para kyai jarang atau bahkan tidak menggunakan media apapaun. Hanya untuk beberapa kajian kitab tertentu, seperti materi yang berkaitan dengan ilmu alat, para kyai menggunakan media papan tulis dan alat tulisnya. Kondisi seperti ini tertentu kurang efektif dalam meningkatkan kualitas pembelajaran atau memperluas dakwah ke masyarakat luas. Dakwah di era digital, terutama dalam konteks sosial keagamaan, tantangan pesantren di Era revolusi industri 4.0, selain menghadapi pertarungan ideologiideologi besar dan kecanggihan teknologi informasi dan komunikasi juga arus globalisasi yang menimbulkan berbagai macam perubahan pola dari segala aspek kehidupan. Tren kenaikan penggunaan internet di kalangan kaum muda milenial berimplikasi terhadap perubahan pola konsumsi generasi tersebut terhadap informasi agama. Fakta itu diperkuat dengan jumlah penonton pengajian berbasis YouTube, Facebook dan media lainnya yang semakin meningkat. (Gazali, 2018)

Dengan demikian, pesantren tidak bisa lagi bersikukuh mengunakan metode konvensional seperti ceramah (sorogan dan bandongan) sebagai satu-satunya teknik dominan dalam menyampaikan materi dakwah 
620 Revitalisasi Pembelajaran Kitab Kuning di Era Revolusi Industri 4.0 bagi Mahasiswa di Pondok Pesantren Tahfidz al-Quran "Oemah al-Quran” Merjosari Lowokwaru Malang- Nur Chanifah DOI: https://doi.org/10.31004/abdidas.v2i3.329

dan pembelajaran, bukan saja karena jangkauan segmen pendengarnya yang terbatas ruang dan waktu tetapi juga terkait fleksibilitas akses terhadap materi dakwah. Media dakwah dan pendidikan yang berbasis teknologi mutlak diperlukan. Karena realitas masyarakat millennial telah dapat mengakses ceramah, tausiyah dan materi dakwah secara mudah di mana pun dan kapan pun mereka menginginkannya maka secara perlahan media sosial telah banyak memberi pengaruh pemahaman agama terutama anak muda "zaman now". Kondisi ini perlu menjadi perhatian pesantren dalam mengimbangi literatur keislaman yang tersebar melalui media sosial (Medsos) terutama pesan-pesan yang mengandung biasbias ideologi konservatif yang intoleran, liberal dan radikal dengan memproduksi literatur keislaman yang moderat, humanis dan toleran berbantukan teknologi (Gazali, 2018).

Perubahan dan kemajuan revolusi industri 4.0 tersebut juga telah membawa babak baru bagi peradaban manusia. Daya jangkau yang sangat luas membuat interaksi manusia dalam dimensi ruang dan waktu semakin tak terbatas. Perangkat teknologi sejatinya diciptakan untuk memudahkan manusia dalam menjalani berbagai aktivitas kehidupan sehingga memicu perubahan sikap, perilaku, dan cara hidup yang semakin efisien dan produktif, serta perubahan gaya hidup yang semakin modern. Untuk itu, penting dilakukan upaya revitalisasi media pembelajaran kitab kuning di pesantren. Para kyai atau ustadz diharapkan melek teknologi agar bisa merespon perubahan dan perkembangan peradaban manusia, sehingga pembelajarannya bisa lebih kontekstual sebagai bekal santri ketika mereka sudah keluar dari pesantren dan hidup di tengah-tengah masyarakat (Khoirurrijal, 2019).
Dalam Kamus Besar Bahasa Indonesia (KBBI) yang diterbitkan oleh Departemen Pendidikan dan Kebudayaan, disebutkan bahwa revitalisasi adalah proses, cara, perbuatan memvitalkan (menjadikan vital) (Kebudayaan, 1995). Dengan kata lain, revitalisasi merupakan suatu upaya untuk melakukan perubahan dalam diri organisasi dalam rangka memperbaiki sistem administrasi dan untuk memecahkan permasalahan yang dihadapi karena berdasarkan pengalaman organisasi tersebut dapat berfungsi sebagaimana mestinya. Dengan demikian, revitalisasi atau revivalism sistem pendidikan pesantren dapat diartikan sebagai kesadaran untuk menempatkan atau membangkitkan kembali arti pentingnya kelembagaan tersebut secara proporsional dan kontekstual.

Jika dikaitkan dengan pembelajaran kitab kuning di pesantren, maka revitalisasi dimaknai sebagai usahausaha untuk memberdayakan atau membangkitkan kekuatan kembali pembelajaran kitab kuning. Pondok pesantren bukan semata-mata lembaga pendidikan yang mengajarkan, mengembangkan dan menyebarkan ilmu agama Islam, melainkan juga lembaga kemasyarakatan yang memiliki pranata sendiri yang memiliki fungsi amal terhadap masyarakat serta hubungan tata nilai dengan kultur masyarakat, khususnya yang ada dalam lingkungan pengaruhnya. Dalam hal ini, idealnya, pesantren bukan hanya lembaga yang menyelenggarakan kegiatan pendidikan bagi para santrinya, namun bisa mengayomi masyarakat sekitarnya. (Sadali, 2020)

Pondok pesantren Tahfidz Al-Qur'an (PPTQ) Oemah Al-Qur'an merupakan salah satu pondok pesantren yang fokus pada Tahfidz Al-Qur'an yang berada di Kota Malang yang perkembangannya signifikan. Semua santri yang mondok di sana berstatus mahasiswa. Pada mulanya sekitar tahun 2012, pesantren 
621 Revitalisasi Pembelajaran Kitab Kuning di Era Revolusi Industri 4.0 bagi Mahasiswa di Pondok Pesantren Tahfidz al-Quran "Oemah al-Quran” Merjosari Lowokwaru Malang- Nur Chanifah DOI: https://doi.org/10.31004/abdidas.v2i3.329

ini merupakan asrama bagi mahasiswi yang ingin mengaji dan menghafalkan Al-Qur'an. Jumlah santri yang pertama tinggal di asrama tersebut sebanyak 7 mahasiswi yang berasal dari berbagai perguruan tinggi di Kota Malang, di antaranya adalah adalah mahasiswi UIN, UB, dan UNISMA. Jumlah santri dari tahun ke tahun terus semakin banyak, hingga pada akhirnya asrama tersebut diresmikan menjadi pesantren sekitar tahun 2015. Alasannya, santri yang menempat semakin banyak dan sulit dikontrol keamanan dan ketertibannya. Saat ini santrinya tercatat hampir 100 anak.

Sejak diresmikan menjadi Pesantren tahun 2015 tersebut, kegiatan dan peraturan yang ada di pesantren tersebut semakin tertata dan terkontrol dengan baik. Kurikulum yang diselenggarakan juga semakin baik. Meskipun pesantren tersebut fokus pada kegiatan tahfidz Al-Qur'an, namun banyak kegiatan penunjang lain yang juga diselenggarakan di pesantren tersebut untuk menunjang tahfidz Al-Qur'an. Di antara kegiatan tersebut adalah madrasah diniyyah yang diselenggarakan setiap hari setelah magrib, kegiatan pengembangan bahasa, muhadharah, international day dan lain-lain (Oktavioni, 2021).

Dalam kegiatan madrasah diniyyah diajarkan beberapa kitab kuning yang menunjang program tahfidz. Di antara kitab yang diajarkan yaitu Tibyan bi adabi hamalatil Quran, tafsir al-Munir, Lubabul hadis, durorul bahiyyah, khulashoh abi Jamrah, dan Arba'in nawawai (Oktavioni, 2021). Selama ini kegiatan pembelajarannya masih bersifat konvensional. Padahal saat ini, tantangan pesantren semakin berat dan para santri harus bisa memberikan kontribusi menghadapi tantangan tersebut. Untuk itu, maka dalam media pembelajarannya perlu ada revitalisasi agar para mahasiswa sebagai agent of change bisa semakin luas wawasannya dan mampu mengimplemetasikan apa yang dia pelajari dari kitab tersebut untuk menghadapi globalisasi saat ini.

Namun demikian, meskipun santrinya sudah semakin banyak dan kegiatan madrasah juga sudah berjalan dengan tertib, tetapi media pembelajaran yang tersedia di pondok tersebut belum ada, sehingga pembelajarannya kurang konstektual dengan kondisi saat ini. Masyarakat sekitar juga belum mendapat banyak manfaat dari pembelajaran itu karena tidak adanya media pembelajaran yang tersedia. Untuk itu kegiatan pengabdian masyarakat ini mengupayakan untuk memberikan solusi berupa revitalisasi pembelajaran kitab kuning sehingga nilai kemanfaatan yang diperoleh semakin banyak dan luas.

\section{METODE}

\section{Pra-Kegiatan}

Sebelum melakukan kegiatan pengabdian berupa revitalisasi pembelajaran kitab kuning di era revolusi industri 4.0, terlebih dahulu kami melakukan dialog dan diskusi dengan pengasuh dan ustadz yang mengajar kitab kuning di PPTQ Oemah Al-Qur'an. Dalam kegiatan tersebut kami mencoba memberikan pemahaman akan pentingnya revitalisasi media pembelajaran kitab kuning sehingga pembelajarannya tetap efeketif dan efisien, terutama dalam menghadapi era revolusi industri 4.0. Selanjutnya kami melakukan observasi kegiatan pembelajaran kitab kuning yang selama ini diterapkan di PPTQ Oemah Al-Qur'an Merjosari Malang.

Berdasarkan hasil observasi awal, ternyata kami menemukan bahwa media pembelajaran yang diterapkan dalam pembelajaran kitab kuning masih konvensional. Para ustadz atau ustadzah 
622 Revitalisasi Pembelajaran Kitab Kuning di Era Revolusi Industri 4.0 bagi Mahasiswa di Pondok Pesantren Tahfidz al-Quran "Oemah al-Quran” Merjosari Lowokwaru Malang- Nur Chanifah DOI: https://doi.org/10.31004/abdidas.v2i3.329

menggunakan metode bandongan dengan media papan tulis. Tentu metode tersebut kurang efektif di era revolusi industri 4.0, karena pembelajaran hanya mampu diserap oleh yang hadir di kelas saja sehingga jangkauannya sangat terbatas. Sementara jika ada santri yang izin, masyarakat atau netizen yang ingin mengikuti pembelajaran tidak akan bisa menjangkau pembelajaran tersebut padahal saat ini, media sosial diramaikan dengan ustadz-ustadz yang kapasitas keilmuannya masih minim sehingga beberapa kali ditemukan pengajianpengajian yang sering menggunakan kata-kata kotor atau ujaran kebencian, dan rujukan yang tidak jelas atas apa yang disampaikan oleh para ustadz tersebut. Dengan adanya revitalisasi pembelajaran kitab kuning ini, harapannya penyebaran ilmu yang diajarkan di pesantren jangkauannya bisa lebih luas dan bisa mengimbangi dakwah-dakwah yang ada di media sosial. Masyarakat atau netizen bisa lebih mudah menikmati atau belajar agama langsung dari sumbernya, bukan dari "katanya" yang tidak jelas sumbernya.

Proposal akan diseleksi oleh Tim Reviewer Pusat MPK, kemudian bagi proposal terpilih yang didanai diharapkan segera melaksanakan kegiatan sesuai yang direncanakan dalam proposal. Setelah diumumkan bahwa proposal diterima, Tim pengabdian kepada masyarakat segera mempersiapkan kegiatan pengabdian di PPTQ Oemah Al-Qur'an. Di samping itu Tim pengabdian kepada masyarakat juga mempersiapkan materi yang akan disampaikan. Tim juga melakukan persiapan perlengkapan yang dibutuhkan selama kegiatan pengabdian berlangsung.

\section{Saat Kegiatan Berlangsung}

Pada saat kegiatan berlangsung, pertamatama yang dilakukan melakukan pembukaan kegiatan tersebut, oleh Ketua Pengabdian dan Pengasuh PPTQ Oemah Al-Qur'an. Kegiatan berikutnya yang akan dilakukan adalah menyampaikan materi tentang pentingnya revitalisasi pembelajaran kitab kuning demonstrasi penggunaan media dalam pembelajaran kitab kuning di pesantren yang akan disampaikan oleh Dr. Nur Chanifah, M.Pd.I. Setelah itu praktik penggunaan media pembelajaran oleh para ustadz atau ustadzah dan santri yang akan dipandu oleh Drs. Abdul Halim, M.Ag.

Kegiatan tersebut dilaksanakan pada tanggal 22 Juli 2019 di Musholla PPTQ Oemah Al-Qur'an. Peserta dari kegiatan tersebut adalah seluruh santri PPTQ Oemah Al-Qur'an yang jumlahnya ada sekitar 100 santri. Tidak hanya santri, para ustadz dan ustadzah juga ikut dalam kegiatan tersebut.

\section{Pasca Kegiatan}

Setelah kegiatan pengabdian berlangsung, Tim pengabdian kepada santri dan Ustadz melakukan diskusi (tanya jawab) dengan peserta untuk menindaklanjuti sesuatu hal yang belum dipahami oleh peserta. Langkah berikutnya, tim pengabdian masyarakat akan memberikan bantuan perlengkapan untuk meningkatkan kualitas dan syiar dakwah dalam pembelajaran kitab kuning pada masyarakat luas. Bantuan tersebut berupa LCD dan layar proyektor, dan sound system.

\section{HASIL DAN PEMBAHASAN}

Pelaksanaan pengabdian di lakukan dengan mengadakan sosialisasi kepada para ustadz dan santri di 
623 Revitalisasi Pembelajaran Kitab Kuning di Era Revolusi Industri 4.0 bagi Mahasiswa di Pondok Pesantren Tahfidz al-Quran "Oemah al-Quran” Merjosari Lowokwaru Malang- Nur Chanifah

DOI: https://doi.org/10.31004/abdidas.v2i3.329

Pondok Pesantren Tahfidz Al-Qur'an Oemah Al-Qur'an Merjosari Malang. Dalam kegiatan tersebut, tim pengabdian masyarakat memberikan pemahaman kepada para ustadz dan pengasuh akan pentingnya revitalisasi media pembelajaran kitab kuning di era revolusi industry 4.0 agar ruang lingkup dakwahnya semakin luas, tidak hanya untuk santri di pesantren tetapi juga untuk khalayak umum.

Untuk itu, maka tim pengabdian masyarakat pusat MPK mengadakan pelatihan dan pendampingan dalam revitalisasi media pembelajaran kitab kuning bagi mahasantri. Kegiatan tersebut menghasilkan media terbaru dalam pembelajaran kitab kuning, yaitu dengan memanfaatkan media LCD proyektor dan disiarkan live melalui akun media sosial dan YouTube pondok pesantren. Lebih lanjut, dalam proses pelatihan dan pendampingan tersebut, ustadz harus dibiasakan untuk siaran langsung, mengingat ada beberapa ustadz yang belum biasa sehingga grogi dan akhirnya materi tidak tersampaikan dengan baik. Oleh karenanya, perlu ada kegiatan pembiasaan agar tidak grogi dan terbiasa di depan kamera.

Selain itu, untuk menunjang kegiatan pembelajaran, maka ustadz harus banyak untuk mencari informasi yang berkaitan dengan tema yang disajikan agar materi yang disampaikan lebih kontekstual sehingga bisa mudah diterima oleh masyarakat. Informasi tersebut bisa berkaitan dengan peristiwa, fakta, atau isu aktual. Hasilnya akan ditampilkan melalui media LCD dan santri diminta untuk memberikan masukan berdasarkan materi yang sudah dipelajari di kitab. Ini penting dilakukan untuk meningkatkan literasi santri dan mencegah penyebaran berita HOAX. Selain itu, dengan media LCD pemahaman santri terhadap kitab kuning bisa lebih komprehensif, mengingatkan ada contoh peristiwa yang terkait dengan pembelajaran.

Media yang berbasis teknologi tadi juga memudahkan syiar atau penyebaran ilmu tidak hanya kepada santri tetapi juga kepada masyarakat. Hal ini penting dikarenakan, pondok pesantren harus mampu memberikan kontribusi positif bagi masyarakat sekitar khususnya, dan masyarakat luas pada umumnya. Masyarakat bisa lebih mudah mengakses kegiatan pengajian yang diselenggarakan oleh pesantren. Mereka tidak harus datang ke pondok, tetapi bisa diakses di rumah sambil mengerjakan pekerjaan rumah atau di manapun mereka berada. Hasilnya, ada hubungan yang terjalin dengan baik antara pondok pesantren dengan masyarakat.

Ada beberapa langkah dalam implementasi penggunaan media tersebut dalam pembelajaran kitab kuning:

1. Menyiapkan materi yang akan disajikan dalam pembelajaran. Materi yang disajikan bisa dalam bentuk PPT, video terkait dengan materi, atau $e$ book.

2. Menyiapkan perlengkapan media pembelajaran, seperti akses wifi, laptob, LCD, layar proyektor, tripot dan kamera.

3. Mempresentasikan materi.

4. Tanya jawab dan refleksi atas materi yang disajikan. 


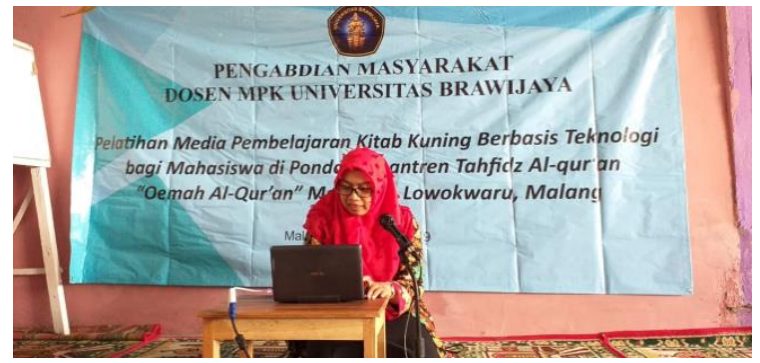

Gambar 1: Kegiatan Persiapan Pembelajaran Kitab Kuning Menggunakan Media LCD

Untuk mengoptimalkan implementasi media tersebut, maka akses Wi-Fi harus kuat agar live streaming tidak terganggu. Selain itu, perlu ada pendampingan kepada user (baik ustadz maupun santri) dalam penggunaan media tersebut, agar materi yang disampaikan tidak salah paham bagi masyarakat, mengingat pembelajarannya diimplementasikan secara langsung maupun tidak langsung. Penggunaan media tersebut akan mempermudah santri atau audience dalam memahami materi. Misalnya, materi tentang rukun sholat yang ada di dalam kitab Taqrib. Untuk memperjelas pemahaman santri, maka setelah ustadz atau kyai membacakan materi pada kitab kemudian dilanjut dengan pemutaran video praktik shalat lengkap. Untuk itu, ustdaz bisa membuat video sendiri terkait dengan materi atau bisa searching di YouTube tentang tutorial praktik shalat lengkap. Link yang bisa direkomendasikan atau digunakan oleh ustadz misalnya https://www.youtube.com/watch?v=TbS0V5g0USs.

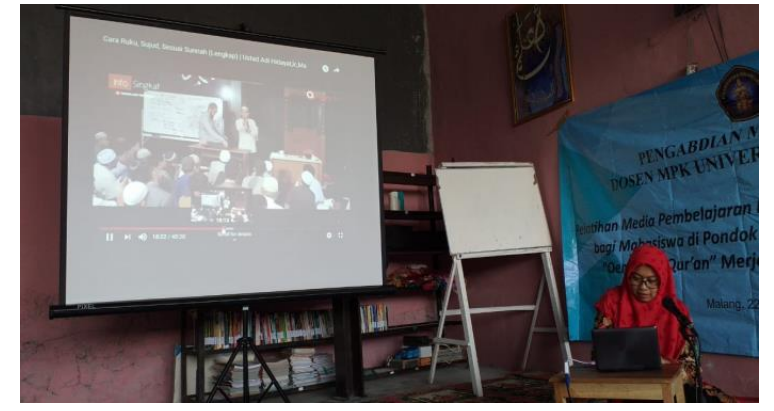

Gambar 2: Kegiatan Pembelajaran dengan Menggunakan Media Video

Berdasarkan media video tersebut, maka pemahaman santri tentang rukun shalat yang ada di kitab taqrib akan lebih baik. Para santri bisa langsung melihat praktik, tidak hanya sekedar teorinya. Akan tetapi, ustadz harus mampu menyeleksi mana video yang sesuai dan mana yang tidak. Hal ini penting dilakukan untuk menghindari kesalahpahaman terhadap masalah khilafiyah dalam Islam.

Dengan demikian, ada beberapa hal yang perlu diperhatikan dalam implementasi media tersebut:

1. Mengubah mindset kyai atau ustdaz tentang perlunya media pembelajaran berbasis teknologi,

2. Penggunaaan media berbasis teknologi harus diimbangi dengan pengetahuan agama yang mendalam agar tidak disalahgunakan,

3. Pengguna media berbasis teknologi harus tetap mengontrol kegiatan pembelajaran secara langsung sebagai upaya untuk mengantisipasi pengaruh negative dari teknologi.

Mengingat dana yang dimiliki oleh pondok pesantren juga minim untuk pengadaan media tersebut, maka tim pengabdian masyarakat memberikan sumbangan berupa LCD proyektor, layar proyektor, dan sound system. Tujuannya agar kegiatan pembelajarannya lebih menarik, mudah dipahami, dan penyebarannya 
625 Revitalisasi Pembelajaran Kitab Kuning di Era Revolusi Industri 4.0 bagi Mahasiswa di Pondok Pesantren Tahfidz al-Quran "Oemah al-Quran” Merjosari Lowokwaru Malang- Nur Chanifah DOI: https://doi.org/10.31004/abdidas.v2i3.329

lebih luas tidak hanya untuk santri tetapi juga masyarakat sekitar.

Berdasarkan hasil evaluasi yang dilakukan oleh tim pengabdian kepada para peserta (santri dan ustadz atau ustadzah), kegiatan pengabdian berjalan dengan lancar dan baik. Sosialisasi dan demonstrasi yang dilakukan oleh tim pengabdian dapat memberikan pencerahan dan membuka wawasan bagi santri dan ustadz atau ustadzah. Tidak hanya itu, kegiatan pengabdian juga memberikan dampak dan manfaat yang siginifikan bagi pesantren dan masyarakat sekitar.

Dari kegiatan pengabdian tersebut, pihak pesantren sangat terbantu dalam meningkatkan kualitas pembelajarannya. Selama ini pihak pesantren masih menggunakan metode konvensional dalam pembelajarannya, sehingga jangkauannya terbatas dan ada beberapa materi juga sulit dipahami karena tidak didukung dengan media yang memadai. Dengan revitalisasi media pembelajaran tersebut, pemahaman santri bisa semakian baik dan jangkauannya menjadi semakin luas, karena tidak hanya bisa diakses oleh santri saja tetapi juga masyarakat luas.

\section{UCAPAN TERIMA KASIH}

Terima kasih kami ucapkan kepada Pusat MPK Universitas Brawijaya yang telah mendanai kegiatan pengabdian masyarakat ini.

\section{SIMPULAN}

Berdasarkan hasil dan pembahasan, dapat disimpulkan bahwa kegiatan pengabdian berupa Revitalisasi Pembelajaran Kitab Kuning di Era Revolusi Industri 4.0 bagi Mahasiswa di Pondok Pesantren Tahfidz Al-Qur'an "Oemah Al-Qur'an” Merjosari Lowokwaru Malang dapat diimplementasikan dengan memperhatikan beberapa hal, yaitu untuk revitalisasi media pembelajaran kitab kuning di Pesantren, maka perlu ada beberapa hal yang perlu diperhatikan, yaitu: 1) mengubah mindset kyai atau ustdaz tentang perlunya media pembelajaran berbasis teknologi, 2) penggunaaan media berbasis teknologi harus diimbangi dengan pengetahuan agama yang mendalam agar tidak disalahgunakan, 3) pengguna media berbasis teknologi harus tetap mengontrol kegiatan pembelajaran secara langsung sebagai upaya untuk mengantisipasi pengaruh negatif dari teknologi. Dampaknya, pemahaman santri menjadi lebih baik dan komprehensif, karena meraka tidak hanya mempelajari teorinya tetapi juga praktiknya secara langsung. para santri juga bisa lebih mudah dalam menganalisis persoalanpersoalan yang muncul di sekitar mereka terkait dengan materi yang disampaikan oleh ustadz.

Berdasarkan hasil evaluasi dengan pihak pondok pesantren, maka perlu ada penambahan fasilitas terkait dengan media yang mampu menunjang pembelajaran kitab kuning berbasis IT. Selain itu, juga perlu adanya pendampingan dan bimbingan lebih lanjut bagi ustadz dan kyai terkait dengan penggunaan media tersebut.

\section{DAFTAR PUSTAKA}

Adawiyyah, S. R. (2017). Manajemen Pembelajaran Kitab Kuning (Studi Kasus di Pondok Pesantren Al-Qur'an Asy Syifa Cicalengka Bandung. Bandung: UIN Gunung Djati.

Arief, A. (2002). Pengantar Ilmu dan Metodologi Pendidikan Islam. Jakarta: Ciputat Press.

Gazali, E. (2018). Pesantren di Antara Generasi Alfa dan Tantangan Dunia Pendidikan Era 
626 Revitalisasi Pembelajaran Kitab Kuning di Era Revolusi Industri 4.0 bagi Mahasiswa di Pondok Pesantren Tahfidz al-Quran "Oemah al-Quran” Merjosari Lowokwaru Malang- Nur Chanifah DOI: https://doi.org/10.31004/abdidas.v2i3.329

Revolusi Industri 4.0. OASIS : Jurnal Ilmiah Kajian Islam Vol. 2, No. 2 Februari 2018 , 95-96.

Kebudayaan, D. P. (1995). Kamus Besar Bahasa Indonesia Edisi Kedua. Jakarta: Balai Pustaka.

Khoirurrijal. (2019). Eksistensi Pesantren di Tengah Kemoderenan Pesantren. Jurnal elHekam, Vol. IV, No. 2, Juli-Desember 2019 , 113.

Mahfudh, M. S. (1994). Nuansa Fiqih Sosial. Yogyakarta: LKis.

Nata, A. (2012). Sejarah Sosial Intelektual Islam. Jakarta: Rajawali Press.

Oktavioni, D. N. (2021). Perancangan Sistem Informasi Akuntansi pada Pondok Pesantren Tahfidz al-Quran Oemah Al-Quran Abu Hanifah Malang. Malang: UIN Maulana Malik Ibrahim.

Sadali. (2020). Eksistensi Pesantren Sebagai Lembaga Pendidikan Islam. ATTA 'DIB Jurnal Pendidikan Agama Islam, Vol. 1, No. 2, Desember 2020 , 54.

Ulum, M. (2018). Eksistensi Pendidikan Pesantren: Kritik Terhadap Kapitalisasi Pendidikan. TA"LIM : Jurnal Studi Pendidikan Islam Vol.1 No.2 Juli 2018, 241.

Wiwin Fitriyah, A. H. (2018). Eksistensi Pesantren dalam Pembentukan Kepribadian Santri. Palapa: Jurnal Studi Keislaman dan Ilmu Pendidikan Volume 6, Nomor 2, November $2018,155$. 